\title{
URGENSI PENERAPAN MANAJEMEN KONFLIK DALAM ORGANISASI PENDIDIKAN
}

\author{
Khoirul Anwar \\ Fakultas Agama Islam UNISSULA Semarang \\ khoirul@unissula.ac.id
}

Abstract

Conflict can be experienced by anyone, and it can happen anywhere, including at school. Students, teachers, or a principal might face to conflict in a certain period of time. If conflict happened at school is not managed and become destructive, then it can disturb school organization and educational efficiency and effectiveness. Conflict can be a serious problem within an organisation, without considering any form of organization and it's complexity. If the conflict continuously happen without solution. Therefore, the skills to manage the conflict through conflict management are needed by every leader, including principal to solve various conflict that happen at school's environment. The principal is demanded to master conflict management skills, thus the conflict happened can get a positive effect to improve the quality of education. The main goal to apply the conflict management within the school organization is to develope and maintain cooperative colaboration among educational organization members, such as: principal, teachers, employees, students and even with people beyond school's community.

Keyword: Conflict, organization, principal and conflict management.

Abstrak

Konflik bisa dialami oleh siapapun dan di manapun, termasuk di sekolah. Peserta didik, guru, atau pun kepala sekolah dalam waktu-waktu tertentu sangat mungkin dihadapkan dengan konflik. Apabila konflik yang terjadi di sekolah tidak terkelola dan bersifat destruktif, maka selain dapat mengganggu organisasi sekolah juga dapat mengganggu terhadap pencapaian efektivitas dan efisiensi pendidikan. Konflik dapat menjadi masalah yang serius dalam setiap organisasi, tanpa peduli apapun bentuk dan tingkat kompleksitas organisasi tersebut, jika konflik tersebut dibiarkan berlarut-larut tanpa penyelesaian. Karena itu keahlian untuk mengelola konflik melalui manajemen konflik sangat diperlukan bagi setiap pimpinan, termasuk kepala sekolah dalam menyelesaikan berbagai konflik yang terjadi di lingkungan sekolah. Kepala sekolah dituntut menguasai manajemen konflik agar konflik yang muncul dapat berdampak positif untuk meningkatkan mutu pendidikan. Tujuan utama menerapkan managemen konflik dalam organisasi sekolah adalah untuk membangun dan mempertahankan kerja sama yang kooperatif dengan pihak-pihak yang ada dalam organisasi pendidikan, yakni kepala sekolah, tenaga pendidik, tenaga kependidikan, dan peserta didik, bahkandengan pihak luar.

Kata kunci: Konflik, organisasi, kepala sekolah dan manajemen konflik. 


\section{A. PENDAHULUAN}

Organisasi terdiri dari berbagai macam komponen yang berbeda dan saling memiliki ketergantungan dalam proses kerjasama untuk mencapai tujuan tertentu. Perbedaan yang terdapat dalam organisasi seringkali menyebabkan terjadinya ketidakcocokan yang akhirnya menimbulkan konflik. Hal ini disebabkan karena pada dasarnya ketika terjadi suatu organisasi, maka sesungguhnya terdapat banyak kemungkinan timbulnya konflik. Setiap organisasi yang melibatkan banyak orang, di samping ada kerjasama untuk mencapai tujuan organisasi itu juga tidak jarang terjadi perbedaan pandangan, ketidakcocokan dan pertentangan di antara mereka yang mengarah pada konflik. Di dalam organisasi manapun terdapat konflik, baik yang masih tersembunyi maupun yang sudah terang-terangan. Dengan demikian konflik merupakan kewajaran dalam suatu organisasi (Efendi, 2015), termasuk dalam organisasi pendidikan.

Konflik sebenarnya merupakan hal alamiah dalam interaksi dan interelasi sosial antar individu atau antar kelompok. Dahulu konflik dianggap sebagai gejala atau fenomena yang tidak wajar dan berakibat negatif, tetapi sekarang konflik dianggap sebagai gejala yang wajar yang dapat berakibat negatif maupun positif tergantung bagaimana cara mengelolanya. Karena itulah diperlukan upaya untuk mengelola konflik secara serius agar keberlangsungan suatu organisasi tidak terganggu.

Kajian mengenai penyebab atau sumber-sumber konflik dalam organisasi dimaksudkan sebagai dasar pertimbangan bagi pimpinan organisasi khususnya para pemimpin lembaga pendidikan dalam mengendalikan konflik. Apabila berbagai konflik dikelola secara baik, maka konflik dapat dimanfaatkan sebagai media untuk mengkritisi kinerja organisasi. Dengan demikian keberadaan konflik tidak perlu dipandang sebagai peristiwa yang merisaukan bagi pimpinan, tetapi justru dengan munculnya konflik, organisasi menjadi dinamis.

Mengatasi dan menyelesaikan suatu konflik bukanlah suatu yang sederhana. Cepat-tidaknya suatu konflik dapat diatasi tergantung pada kesediaan dan keterbukaan pihak-pihak yang bersengketa untuk menyelesaikan konflik, berat ringannya bobot atau tingkat konflik tersebut serta kemampuan campur tangan (intervensi) pihak ketiga yang turut berusaha mengatasi konflik yang muncul. Manajemen konflik sangat berpengaruh bagi anggota organisasi. Pemimpin organisasi dituntut menguasai manajemen konflik agar konflik yang muncul dapat berdampak positif untuk meningkatkan mutu organisasi. Manajer menghabiskan 20 persen dari waktu kerja mereka berhadapan dengan konflik. Dalam hal ini, manajer bisa saja sebagai pihak pertama yang langsung terlibat dalam konflik tersebut, dan bisa pula sebagai mediator atau pihak ketiga, yang perannya tidak lain dari menyelesaikan konflik antar pihak lain yang mempengaruhi organisasi maupun individual yang terlibat di dalam organisasi yang ditanganinya (Wirawan, 2013) Sudah menjadi tuntutan alam dalam posisi dan kewajiban sebagai manajer untuk selalu dihadapkan pada konflik. Salah satu titik penting dari tugas seorang manajer dalam melaksanakan komunikasi yang efektif di dalam organisasi yang ditanganinya adalah memastikan bahwa arti yang dimaksud dalam instruksi yang diberikan akan sama dengan arti yang diterima oleh penerima instruksi demikian pula sebaliknya Hal ini harus menjadi tujuan seorang manejer dalam semua komunikasi yag dilakukannya dalam menangani sebuah konflik.

Dari latar belakang di atas, maka permasalahan yang akan dibahas dalam tulisan ini adalah tentang manajemen konflik, tujuan, model dan urgensinya dalam menyelesaikan berbagai konflik di lembaga pendidikan :

\section{B. PEMBAHASAN}

I. Pengertian Konflik dan Manajemen Konflik Konflik merupakan sesuatu yang tidak dapat dihindarkan dalam kehidupan. Bahkan sepanjang kehidupan, manusia senantiasa dihadapkan dan bergelut dengan konflik. Demikian halnya dengan kehidupan organisasi. Anggota organisasi senantiasa dihadapkan pada konflik. Perubahan atau inovasi baru sangat rentan menimbulkan konflik (destruktif), apalagi jika tidak disertai pemahaman yang memadai terhadap ide-ide yang berkembang. Konflik secara etimologi berasal dari bahasa Inggris yaitu conflict, dari bahasa Latin configure yang berarti saling menjatuhkan atau konflik terjadi karena ada pihak-pihak yang saling 
mengejutkan dengan kata lain kekerasan, sindiran, sikap, pendapat-pendapat, perilaku, tujuan-tujuan, dan kebutuhan yang bertentangan (Rusdiana, 2016).

Secara terminologi, ada beberapa pengertian yang dijelaskan para ahli, antara lain: Afzalur Rahim menyatakan bahwa konflik dapat didefinisikan sebagai keadaan interaktif yang termanifestasikan dalam sikap ketidakcocokan, pertentangan, atau perbedaan dengan atau antara entitas sosial seperti individu-individu, kelompok-kelompok, atau organisasi-organisasi (Efendi, 2015). Sedangkan Wahjosumidjo (2002) mendefinisikan konflik lebih simpel yaitu, "Segala macam bentuk hubungan antara manusia yang mengandung sifat berlawanan". Konflik organisasi adalah ketidak sesuaian antara dua atau lebih anggota atau kelompok organisasi yang timbul karena adanya kenyataan bahwa mereka harus membagi sumber-sumber daya yang terbatas atau kegiatan kerja dan/atau karena kenyataan bahwa mereka mempunyai perbedaan status, tujuan, nilai, atau persepsi (Rusdiana, 2016).

Substantif konflik merupakan perselisihan yang berkaitan dengan tujuan kelompok, pengalokasian sumber daya dalam suatu organisasi, distribusi kebijaksanaan dan prosedur, dan pembagian jabatan pekerjaan (Mulyasa, 2012). Konflik sering menimbulkan sikap oposisi antara kedua belah pihak, sampai kepada tahap yang menunjukkan pihak-pihak yang terlibat memandang satu sama lain sebagai penghalang dan pengganggu tercapainya kebutuhan dan tujuan masing-masing. Konflik dapat diartikan sebagai ketidak setujuan antara dua atau lebih anggota organisasi atau kelompok-kelompok dalam organisasi yang timbul karena mereka harus menggunakan sumber daya yang langka secara bersama-sama atau menjalankan kegiatan bersama-sama dan atau karena mereka mempunyai status, tujuan, nilai-nilai dan persepsi yang berbeda. Anggota-anggota organisasi yang mengalami ketidaksepakatan tersebut biasanya mencoba menjelaskan duduk persoalannya dari pandangan mereka.

Setiap kelompok dalam satu organisasi, dimana di dalamnya terjadi interaksi antara satu dengan lainnya, memiliki kecenderungan timbulnya konflik. Konflik sangat erat kaitannya dengan perasaan manusia, termasuk perasaan diabaikan, disepelekan, tidak dihargai, ditinggalkan, dan juga perasaan jengkel karena kelebihan beban kerja. Perasaan-perasaan tersebut sewaktu-waktu dapat memicu timbulnya kemarahan. Keadaan tersebut akan mempengaruhi seseorang dalam melaksanakan kegiatannya secara langsung, dan dapat menurunkan produktivitas kerja organisasi secara tidak langsung dengan melakukan banyak kesalahan yang disengaja maupun tidak disengaja. Konflik juga dapat diartikan sebagai ketidaksetujuan antara dua atau lebih anggota organisasi atau kelompok-kelompok dalam organisasi yang timbul karena mereka harus menggunakan sumber daya yang langka secara bersama-sama atau menjalankan kegiatan bersama-sama dan atau karena mereka mempunyai status, tujuan, nilai-nilai dan persepsi yang berbeda. Anggotaanggota organisasi yang mengalami ketidaksepakatan tersebut biasanya mencoba menjelaskan duduk persoalannya dari pandangan mereka. Sikap saling mempertahankan diri sekurang-kurangnya di antara dua kelompok, yang memiliki tujuan dan pandangan berbeda, dalam upaya mencapai satu tujuan sehingga mereka berada dalam posisi oposisi, bukan kerjasama.

Konflik menimbulkan akibat-akibat atau resikoresiko tertentu, disamping juga terkadang ada dampak positifnya. G.W. Allport sebagaimana dikutip Hanson, menyatakan bahwa semakin banyak sarjana sosial yang memaparkan bahwa konflik itu sendiri bukan kejahatan, tetapi lebih merupakan suatu gejala yang memiliki pengaruh-pengaruh konstruktif atau destruktif tergantung pada manajemennya ( Hanson, 2010). Menurut Ross (1993) bahwa manajemen konflik merupakan langkah-langkah yang diambil para pelaku atau pihak ketiga dalam rangka mengarahkan perselisihan ke arah hasil tertentu yang mungkin atau tidak mungkin menghasilkan suatu akhir berupa penyelesaian konflik dan mungkin atau tidak mungkin menghasilkan ketenangan, hal positif, kreatif, bermufakat, atau agresif. Manajemen konflik dapat melibatkan bantuan diri sendiri, kerjasama dalam memecahkan masalah (dengan atau tanpa bantuan pihak ketiga) atau pengambilan keputusan oleh pihak ketiga. Suatu pendekatan yang berorientasi pada proses manajemen konflik menunjuk pada pola komunikasi (termasuk perilaku) para pelaku 
dan bagaimana mereka mempengaruhi kepentingan dan penafsiran terhadap konflik (Umam, 2012). Manajemen konflik adalah suatu proses pembuatan rencana dan mengendalikan kondisi yang tidak sesuai dan terjadi di antara pihak-pihak. yang bertikai. Juga berarti suatu proses membuat perencanaan, pengorganisasian, memimpin dan mengendalikan berbagai usaha anggota dalam organisasi dan menggunakan semua sumber daya dari organisasi untuk mencapai sebuah tujuan tertentu. Manajemen konflik sebagai proses pihak yang terlibat konflik atau pihak ketiga menyusun strategi konflik dan menerapkannya untuk mengendalikan konflik agar menghasilkan resolusi yang diinginkan (Wirawan, 2013).

Manajemen konflik merupakan serangkaian aksi dan reaksi antara pelaku maupun pihak luar dalam suatu konflik. Manajemen konflik termasuk pada suatu pendekatan yang berorientasi pada proses yang mengarahkan pada bentuk komunikasi (termasuk tingkah laku) dari pelaku maupun pihak luar dan bagaimana mereka mempengaruhi kepentingan (interests) dan interpretasi. Bagi pihak luar (di luar yang berkonflik) sebagai pihak ketiga, yang diperlukannya adalah informasi yang akurat tentang situasi konflik. Hal ini karena komunikasi efektif di antara pelaku dapat terjadi jika ada kepercayaan terhadap pihak ketiga (Rusdiana, 2015).

Manajemen konflik merupakan langkah-langkah yang diambil para pelaku atau pihak ketiga dalam rangka mengarahkan perselisihan ke arah hasil tertentu yang mungkin atau tidak mungkin menghasilkan penyelesaian konflikdanketenangan, hal positif,kreatif,danbermufakat.

Manajemen konflik merupakan serangkaian aksi dan reaksi antara pelaku maupun pihak luar dalam suatu konflik. Pada prinsipnya, konflik yang timbul dalam penyelenggaraan satuan pendidikan adalah sebagai suatu yang wajar dan dominan. Selain itu, konflik merupakan dinamisator organisasi. Pandanglah bahwa organisasi tanpa konflik bermakna diam, statis, dan tidak mencapai kemajuan yang diharapkan

\section{Tujuan Manajemen Konflik}

Tujuan utama manjemen konflik adalah untuk membangun dan mempertahankan kerja sama yang kooperatif dengan para bawahan, teman sejawat, atasan dan pihak luar. Beberapa bentuk perilaku manajemen konflik seperti tawar menawar, dan pemecahan masalah secara integrative, merupakan pendekatan untuk menangani konflik yang menyangkut seorang manajer dan pihak lain yang bantuannya dibutuhkan untuk mencapai sasaran pekerjaan. Berkaitan dengan manajemen konflik, Fisher sebagaimana dikutip Rusdiana (2015:I7I) menggunakan istilah transformasi konflik secara lebih umum dalam menggambarkan situasi dan tujuan secara keseluruhan, yaitu sebagai berikut : a. Pencegahan konflik bertujuan untuk mencegah timbulnya konflik yang keras.

b. Penyelesaian konflik bertujuan untuk mengakhiri perilaku kekerasan melalui persetujuan damai.

c. Pengelolaan konflik bertujuan untuk membatasi dan menghindarikekerasan denganmendorongperubahan perilaku positif bagi pihak-pihak yang terlibat.

d. Resolusi konflik menangani sebab-sebab konflik dan berusaha membangun hubungan baru dan tahan lama di antara kelompok-kelompok yang berkonflik.

e. Transformasi konflik mengatasi sumber-sumber konflik sosial dan politik yang lebih luas dan berusaha mengubah kekuatan negative dari peperangan menjadi kekuatan sosial dan politik yang positif.

Tahapan-tahapan di atas merupakan satu kesatuan yang harus dilakukan dalam mengelola konflik sehingga setiap tahap akan melibatkan tahap sebelumnya, misalnya pengelolaan konflik akan mencakup pencegahan dan penyelesaian konflik (Rusdiana, 20I5).

\section{Penerapan Manajemen Konflik}

Upaya penanganan konflik sangat penting dilakukan, hal inidisebabkan karena setiapjenis perubahan dalam suatu organisasi cenderung mendatangkan konflik. Perubahan institusional yang terjadi, baik direncanakan atau tidak, tidak hanya berdampak pada perubahan struktur dan personalia, tetapi juga berdampak pada terciptanya hubungan pribadi dan organisasional yang berpotensi menimbulkan konflik.

Di samping itu, jika konflik tidak ditangani secara baik dan tuntas, maka akan mengganggu keseimbangan sumberdaya, dan menegangkan hubungan antara orang-orang yang terlibat. 
Menghadapi konflik yang tidak terelakkan dalam sebuah organiasi, maka konflik yang timbul ini hendaklah dikelola sehingga dapat menjadi sebuah alat yang digunakan organisasi dalam proses beradaptasi atas perubahan yang terjadi. Pemimpin organisasi harus bisa mengambil sikap dengan cepat, karena jika tidak segera diatasi akan menyebabkan tersendatnya pertumbuhan organisasi itu sendiri. Untuk menangani konflik ada tiga tahapan dalam mengelola konflik, yaitu: a. Perencanaan analisis konflik. Pada tahap ini dilakukan identifikasi konflik yang terjadi, untuk menentukan sumber penyebab dan pihak-pihak yang terlibat dalam konflik tersebut. Jika konflik sudah dalam tahap terbuka akan dapat mudah dikenal, tetapi jika masih dalam tahap potensi (tersembunyi) perlu diberi stimulus akan menjadi terbuka dan dapat dikenal.

b. Evaluasi konflik. Pada tahap ini dilakukan evaluasi apakah konflik tersebut sudah mendekati titik patah, sehingga perlu diredam agar tidak menimbulkan dampak negatif. Atau konflik tersebut masih berada ada sekitar titik kritis yang justru menimbulkan dampak positif. Atau justru baru dalam tahap tersembunyi, sehingga perlu diberi stimulus agar mendekati titik kritis dan memberikan dampak positif.

c. Memecahkan konflik. Pada tahap ini kepala sekolah mengambil tindakan untuk mengatasi konflik yang terjadi,termasukmemberistimulusjikamemangkonflik masih dalam tahap tersembunyi dan perlu dibuka.

Konflik merupakan sesuatu yang tidak dapat dihindarkan dalam kehidupan. Bahkan sepanjang kehidupan, manusia senantiasa dihadapkan dan bergelut dengan konflik. Demikian halnya dengan kehidupan organisasi. Anggota organisasi senantiasa dihadapkan pada konflik. Perubahan atau inovasi baru sangat rentan menimbulkan konflik (destruktif), apalagi jika tidak disertai pemahaman yang memadai terhadap ide-ide yang berkembang.

Ada tiga sudut pandang terhadap konflik yang terjadi dalam organisasi, yaitu aliran tradisional, aliran behavioral, dan aliran interaksi. Pertama, aliran tradisional menyatakan bahwa konflik dipandang sebagai sesuatu yang jelek, tidak menguntungkan, dan selalu menimbulkan kerugian dalam organisasi. Oleh karena itu, konflik harus dihindari dan dicegah dengan cara menemukan sumbernya dan diatasi. Kedua, aliran behavioral memandang konflik sebagai sesuatu yang alamiah, wajar terjadinya dalam organisasi, karena tanpa dicipta, konflik mesti terjadi dalam organisasi.

Atas dasaritu,konflik tidakselamanyamerugikan, tetapi juga dapat menguntungkan bilamana dikelola dengan baik. Ketiga, aliran interaksi yang memandang konflik dalam suatu organisasi seharusnya diciptakan (dirangsang). Pandangan ini dilatarbelakangi oleh konsep bahwa "organisasi yang tenang, harmonis, penuh kedamaian, maka kondisinya akan menjadi statis, mandek (stagnasi) dan tidak inovatif. Akibat selanjutnya organisasi tidak dapat bersaing untuk maju (Soetopo, 2016). Konflik dapat menguntungkan dan juga dapat merugikan dalam kehidupan organisasi secara nyata. Konflik yang menguntungkan disebut konflik fungsional, sedangkan konflik yang merugikan disebut konflik disfungsional. Konflik akan menjadi fungsional atau bermanfaat apabila kedua belah pihak yang berkonflik saling menyemangati untuk saling memperbaiki kesalahan masing-masing, bukannya saling menjatuhkan, saling menghalangi pencapaian tujuan, dan saling mementingkan kepentingan sendiri. Karena hal inilah yang dapat menyebabkan konflik menjadi disfungsional atau merugikan (Triatna, 2015).

Metode yang sering digunakan untuk menangani konflik adalah pertama dengan mengurangi konflik; kedua dengan menyelesaikan konflik. Untuk metode pengurangan konflik salah satu cara yang sering efektif adalah dengan mendinginkan persoalan terlebih dahulu (cooling thing down). Meskipun demikian cara semacam ini sebenarnya belum menyentuh persoalan yang sebenarnya. Cara lain adalah dengan membuat "musuh bersama", sehingga para anggota di dalam kelompok tersebut bersatu untuk menghadapi "musuh" tersebut. Cara semacam ini sebenarnya juga hanya mengalihkan perhatian para anggota kelompok yang sedang mengalami konflik. Cara kedua dengan metode penyelesaian konflik. Cara yang ditempuh adalah dengan mendominasi atau menekan, berkompromi dan penyelesaian masalah secara integratif. 4. Manfaat Manajemen Konflik

Konflik merupakan hal yang tidak dapat dihindari 
dan selalu ada dalam kehidupan sosial. Begitu juga halnya dalam sebuah organisasi, dimana individu-individu yang ada di dalamnya seringkali dihadapkan pada konflik.

Adanya perubahan atau inovasi dapat menjadi timbulnya konflik, terlebih jika tidak dibarengi dengan pemahaman yang baik terhadap ide-ide baru. Tidak semua konflik merugikan organisasi, konflik yang ditata dan dikendalikan dengan baik dapat menguntungkan organisasi sebagai satu kesatuan.

Untuk menata konflik dalam organisasi diperlukan keterbukaan, kesabaran serta kesadaran semua pihak yang terlibat maupun yang berkepentingan dengan konflik yang terjadi dalam organisasi (Subandi, 2016).

Ada beberapa perusahaan yang sengaja merekayasa sehingga menimbulkan konflik. Hal ini dilakukan karena bagi perusahaan strategi manajemen konflik justru dapat mendongkrak motivasi karyawan dalam berkompetisi, Tapi dalam beberapa kondisi, koflik tersebutmalahmenyebabkan perusahaandankaryawannya sulit berkembang secara profesional. Mau tidak mau manajemen konflik akan sangat mempengaruhi individuindividu yang ada dalam sebuah organisasi. Karena itu pemimpin dalam organisasi harus memiliki kemampuan manajemen konflik yang memadai, sehingga konflik yang muncul akan membawa dampak positif bagi organisasi.

Pertanyaan yang mungkin timbul di benak kita, mengapa organisasi harus mengembangkan manajemen konflik?. Manajemen konflik dalam organisasi akan memungkinkan organisasi tersebut untuk: a. Evaluasi sistem

Perusahaan dan lembaga pendidikan tidak dapat mengevaluasi efektivitas sistem jika tidak terjadi konflik dalam organisasi. Konflik yang konstruktif akan membantu perusahaan dan lembaga pendidikan dalam mengindentifikasi apakah sistem yang sudah dilakukan berjalan efektif atau memerlukan perbaikan. b. Mengembangkan kompetensi

Penanganan manajemen konflik dengan tepat yang didukung dengan strategi dan sistem akan membantu organisasi mengembangkan kompetensinya, terlebih dalam hal kompetensi non teknis. Manajemen konflik dapat meningkatkan skill organiasi dalam hal penanganan konflik internal sehingga organisasi menjadi lebih kuat. I. Mananajemen Konflik pada Organisasi Pendidikan
Konflik dapat diartikan sebagai suatu kondisi dimana seseorang dihadapkan dengan motif, keyakinan, nilai dan tujuan yang saling bertentangan. Konflik dapat dialami oleh siapapun dan di manapun, termasuk oleh komunitas di sekolah. Siswa, guru, atau pun kepala sekolah dalam waktu-waktu tertentu sangat mungkin dihadapkan dengan konflik. Dalam dunia pendidikan, dibutuhkan seorang kepala sekolah yang mampu menyelesaikan konflik yang terjadi di lembaganya. Manajemen konflik pendidikan dapat diartikan sebagai suatu langkah yang diambil oleh kepala sekolah untuk mengelola konflik yang terjadi sehingga tujuan pendidikan dapat terwujud secara optimal Konflik yang dialami individu di sekolah dapat hadir dalam berbagai bentuk, bisa dalam bentuk individu dengan individu, individu dengan kelompok atau kelompok dengan kelompok. Misalnya, seorang guru berhadapan seorang guru, seorang guru berhadapan dengan sekelompok guru, sekelompok guru tertentu berhadapan dengan sekelompok guru lainnya., dan sejenisnya. Konflik yang terjadi di antara mereka bisa bersifattertutup,terbukaataubahkanmenjadikonfrontasi. Faktor-faktor yang dapat menimbulkan adanya konflik dalam suatu organisasi pendidikan antara lain adalah: berbagai sumber daya yang langka ditemukan di sekolah, perbedaan dalam tujuan antara kepala sekolah dengan guru, saling ketergantungan dalam menjalankan pekerjaan, perbedaan dalam nilai atau persepsi. Selain sebab-sebab di atas, ada juga sebab lain yang mungkin dapat menimbulkan konflik dalam pendidikan misalnya gaya seseorang dalam bekerja, ketidakjelasan organisasi (terutama lembaga swasta) dan masalah-masalah komunikasi yang tidak terarah. Apabila konflik yang terjadi di sekolah tidak terkelola dan bersifat destruktif, maka selain dapat mengganggu kesehatan dan kualitas kehidupan seseorang, juga dapat mengganggu terhadap pencapaian efektivitas dan efisiensi pendidikan di sekolah secara keseluruhan.

Apabila konflik mengarah pada kondisi destruktif, maka hal ini dapat berdampak pada penurunan efektivitas kerja dalam organisasi, baik secara perorangan maupun kelompok. Biasanya tiap kelompok berupaya melakukan berupa penolakan, resistensi terhadap perubahan, apatis, acuh tak acuh, bahkan mungkin 
muncul luapan emosi destruktif, berupa demonstrasi.

Selain itu fungsi manajemen konflik pendidikan adalah untuk menghindari konflik, Mengakomodasi (memberi kesempatan pada orang lain untuk mengatur strategi pemecahan masalah, khususnya apabila isu tersebut penting bagi orang lain), kompetisi, kompromi atau negosiasi, memecahkan masalah atau kolaborasi.

Pimpinan satuan pendidikan harus memiliki kekuatan dan otoritas sebagai pimpinan pendidikan. Ia harus dapat mendayagunakan kekuatan yang ada pada dirinya dan mampu memanfaatkan otoritas yang ada pada dirinya untuk mengarahkan sikap dan perilaku bawahan. Dengan demikian konflik yang ada harus dikoordinir agar dinamika yang terjadi benar-benar dapat menjadi sesuatu yang positif untuk menghasilkan perubahan sekaligus mendukung perkembangan dan pencapaian tujuan pendidikan.

Konflik di sekolah dapat menimbulkan dampak positif dan negatif, serta dapat mendorong inovasi, kreatifitas dan adaptasi. Sekolah yang tidak berkembang bisa jadi disebabkan oleh kepala sekolah yang terlalu mudah merasa puas dengan prestasi yang telah dicapai, sehingga kurang peka terhadap perubahan lingkungan, dan tidak ada perbedaan pendapat maupun gagasan baru. Meskipun konflik sering bermanfaat bagi kemajuan sekolah, tetapi dapat menurunkan kinerja, menimbulkan ketidakpuasan, meningkatkan ketegangan dan stres (Mulyasa, 2012).

Model-model manajemen konflik penting untuk diterapkan dalam mengatasi konflik di sekolahsekolah. Model-model penanganan konflik yang terkemuka adalah : persaingan, penghindaran, kolaborasi, kompromi dan akomodasi. Model ini dideskripsikan sebagai model yang fokus pada kekuasaan dan kemungkinan merupakan pendekatan yang benar.

Model yang kedua adalah model menghindar, model ini merupakan model yang tidak tegas/asertif dan tidak kooperatif dimana seseorang terlibat dalam pekerjaan tidak untuk kepentingan pribadinya maupun untuk mengganggu kelompok lain. Ini merupakan pendekatan terbaik karena sesuai dengan prinsip. Pendekatan kolaborasi merupakan kebalikan dari model menghindar dan ditandai oleh sifat tegas/asertif maupun kooperatif. Model ini fokus pada pemuasan kebutuhan kedua belah pihak yang terlibat. Dalam hal ini kedua kelompok setuju untuk bekerjasama. Pendekatan kolaboratif untuk manajemen konflik, kami berargumentasi, kemungkinan memperkuat tingkat kepercayaandankerjasamaantarapemimpindanpengurus.

Kolaborasi kemungkinan merupakan strategi yang berguna khususnya bagi penyelesaian konflik yang melibatkan stakeholder dengan kekuasaan yang berbeda. Model kompromi merupakan pendekatan cara tengah bagi manajemen konflik, model ini antara ketegasan/assertif dan kooperatif dan menjadi efektif jika kedua belah pihak bersedia berkorban untuk meraih kesepakatan. Yang terakhir ialah model akomodasi yang ditandai oleh ketidaktegasan dan kekooperatifan dan model ini merupakan kebalikan dari model kompetisi. Pada model ini, individu mengalahkan kepentingan mereka sehingga dapat mengakomodir kebutuhan-kebutuhan lawan (Ghaffar, 20II).

\section{KESIMPULAN}

Berdasarkan hasil pembahasan di atas maka diperoleh kesimpulan sebagai berikut:

I. Konflik adalah segala macam bentuk hubungan antara manusia yang mengandung sifat berlawanan. Sedangkan manajemen konflik merupakan langkahlangkah yang diambil para pelaku atau pihak ketiga dalam rangka mengarahkan perselisihan ke arah hasil tertentu yang mungkin atau tidak mungkin menghasilkan penyelesaian konflik dan ketenangan, hal positif, kreatif dan bermufakat.

2. Tujuan utama manjemen konflik adalah untuk membangun dan mempertahankan kerja sama yang kooperatif dengan para bawahan, teman sejawat, atasan dan pihak luar.

3. Model-model manajemen konflik penting untuk diterapkan dalam mengatasi konflik di sekolahsekolah. Model-model penanganan konflik yang terkemuka adalah : persaingan, penghindaran, kolaborasi, kompromi dan akomodasi.

4. Konflik di sekolah dapat menimbulkan dampak positif dan negatif, serta dapat mendorong inovasi, kreativitas dan adaptasi tergantung sejauhmana penerapan manajemen konflik dalam mengatasi konflik. Untuk itu, manajemen konflik 
sangat urgen untuk diterapkan dalam organisasi pendidikan. Berdasar dari kenyataan tersebut, kepala sekolah harus memiliki kemampuan manajemen konflik yang memadai, sehingga konflik yang muncul di sekolah justru akan membawa dampak positif bagi kemajuan sekolah.

\section{DAFTAR PUSTAKA}

Efendi, Nur, 20I5. Islamic Educational Leadership, Yogyakarta: Kalimedia. Fahmi, Irham, 2016, Perilaku Organisasi Teori, Aplikasi, dan Kasus, Bandung: Alfabeta. Ghaffar, Abdul, 20II, Conflict in Schools: Its Causes \& Management Strategis, Journal of Managerial Sciences Volume III, number II. Hanson, Mark, 2010, Educational Administration and Organizational Behavior, Boston: Allyn and Bacon.

Mulyasa, 2012, Manajemen \& Kepemimpinan Kepala Sekolah, Jakarta: Bumi Aksara. Rusdiana, 2015, Manajemen Konflik, Bandung: Pustaka Setia. ----------. 2016. Pengembangan Organisasi Lembaga Pendidikan, Bandung: Pustaka Setia. Soetopo, Hendyat, 2016, Perilaku Organisasi Teori dan Praktik di Bidang Pendidikan, Bandung: Rosda.

Subandi, Bambang, 2016, Manajemen Organisasi dalam Hadis Nabi, Yogyakarta: INDeS.

Triatna, Cepi, 2015, Perilaku Organisasi dalam Pendidikan, Bandung: Rosda.

Umam, Khaerul, 2012, Perilaku Organisasi, Bandung: Pustaka Setia.

Wahjosumidjo, 2002, Kepemimpinan Kepala Sekolah Tinjauan Teoritik dan Permasalahannya, Jakarta: PT. Raja Grafindo Persada. Wirawan, 2013, Konflik dan Manajemen Konflik Teori, Aplikasi, dan Penelitian, Jakarta: Salemba Humanika. 